\title{
The Ambiguous Moral Foundations of the Underground Economy
}

\author{
George L. Priest ${ }^{\dagger}$
}

Most treatments of the underground economy presuppose that underground economies cannot be morally justified. This moral condemnation is suggested by the conventional taxonomy of activities comprising the underground economy itself: illegal, unreported, unrecorded, and informal. A recent U.S. Department of Labor publication, for example, defines the illegal sector of the underground economy as "economic activities pursued in violation of legal statutes defining the scope of legitimate forms of commerce," presenting examples such as prostitution or the trade in drugs. The same publication defines the "unreported economy" as comprising "those economic activities that circumvent or evade ... the tax code"; "the unrecorded economy" as those "that circumvent the institutional rules that define the reporting requirements of government statistical agencies"; and "the informal economy" as "those economic activities that circumvent the costs of ... the laws and administrative rules covering property relationships, commercial licensing," or other governmental regulations. ${ }^{1}$

These various activities are obviously similar in their circumvention of rules or regulations, but they are similar in a deeper sense because their existence is presumed to directly impede legitimate government actions, as well as broader values of the citizenry. For example, in a recent essay, Professor Feige, the most prominent scholar of the underground economy, explains the "conceptual linkage among underground economies" as comprising two elements: concealment and immorality. The intentional concealment of this set of economic activities from government and policymakers biases and distorts economic data-data which the government relies upon to control the economy.

† John M. Olin Professor of Law and Economics, Yale Law School. I am grateful to Leon Lipson, to Franco Romani, to my colleague Owen M. Fiss, and to participants at the Law and Economics Workshop, University of Toronto for comments on earlier drafts, and to the students and participants in a seminar that Professor Fiss and I have offered over several years for many helpful ideas.

1. GREGORY K. SCHOEPFle ET AL., SECRETARIA DEL TRABAJO Y PREVISION SOCIAL DE MEXICO \& U.S. DEP'T OF LABOR, THE UNDERGROUND ECONOMY IN THE UNITED STATES 2, 4 (1992) [hereinafter DEP'T OF [ABOR]. 
To the extent that national accounting systems are based on data sources primarily collected from the formal sector, a large and growing informal economy will play havoc with perceptions of development based on official statistics, and consequently with policy decisions based exclusively on information provided by official sources. ${ }^{2}$

In addition, and more importantly, the underground economy represents a moral challenge to the most basic legal and political institutions of a society. Thus, according to Professor Feige, the "most serious consequence" of illegal activities "is to undermine the stability and responsibility of political, legal and economic institutions that might otherwise serve to facilitate the [economic] development process." 3 He condemns the unreported economy on similar moral grounds: "Tax noncompliance shifts the burden from the dishonest to the honest, increasing the costs of adherence to any system of rules and regulations."4 And finally, Professor Feige regards the impact of informal economic activities as even more harmful: "An often overlooked consequence of growing informality is the unraveling of the social and political fabric."5 Most other treatments in the academic literature share this moral perspective. ${ }^{6}$

This Essay critically examines such moral judgments. It is inspired by two developments of recent times. First, the collapse of the socialist economies of the Soviet Union and Eastern Europe suggests that we must reevaluate our presumptions about the comparative virtue of economic organization by the state versus organization by the market. The debate during the 1930's and 1940's between Lerner and Lange, who demonstrated the theoretical possibility of optimizing societal resources through government planning, and the Austrians, who maintained that only the market could achieve this result, was never closed. Given the subsequent appearance after World War II of a sustained and surviving rivalry between Eastern and Western economies, students of political economy have been required at least to entertain the proposition that government planning might be more successful than a competitive marketplace in attaining such widely held societal goals as the efficient allocation of resources and the equitable distribution of income. The recent abject failure of Eastern-controlled economies in terms of both efficiency and growth (and of even more basic humanistic, environmental, and

2. Edgar L. Feige, Defining and Estimating Underground and Informal Economies: The New Institutional Economics Approach, 18 WORLD DEV. 989, 993 (1990).

3. Id. at 991 .

4. Id. at 993 .

5. Id. Note, however, that in other writings Professor Feige acknowledges some benefits of underground economic activities, though he views these benefits as clearly outweighed by the activities' social harm. Edgar L. Feige, Introduction to THE UNDERGROUND ECONOMIES 1, 9 (Edgar L. Feige ed., 1989).

6. See generally Frank A. Coll, Cheating THE Government (1990); CARL P. Simon \& ANON D. Wadi, Beating the System (1982); David J. Pyle, TAX Evasion and tHe BlaCk EConomy (1989). 
democratic objectives) compels a reconsideration of that position. In an age in which all of the world's great socialist economies have fallen and are moving toward capitalism (however falteringly), it is less clear than before whether the broader public interest is better served by that form of planning that the underground economies evade or by the productive activities of the underground economies themselves.

Second, modern studies of Eastern economies have been supplemented by similar evidence from the Third World and developing economies suggesting that capitalistic energies have succeeded in aiding the poor to a greater extent than have the most ardent efforts of socialist politics. This evidence, too, compels a reevaluation of the role of underground economies in otherwise broadly capitalistic societies.

Although this Essay describes some of the social and political contributions of underground economic activity, it does not claim that all features of underground economies are socially beneficial or congruent with democratic values. The goal of the Essay is more modest: to reorient the dialogue-especially the moral dialogue-concerning underground economies. By necessity, it must also address the broader moral defensibility of capitalism itself.

Part I begins the discussion by presenting illustrations taken from studies of the underground economy in a pre-1989 socialist state and, separately, in a modern developing nation. These examples show how underground economic activities-however violative of established legal norms-represent private efforts to achieve ends widely valued in most societies, such as increasing the wealth of a country and aiding its poor. Part II generalizes this proposition by comparing the relative moral positions of market-based and state-controlled regulatory activities. Over the past century, most defenders of the market have emphasized values such as personal liberty and wealth creation, which most agree are important, ${ }^{7}$ but which many are willing to sacrifice toward the achievement of broader societal goals. Part II defends the market-and, through that defense, underground economic activity - on additional grounds. This defense shows through the example of the underground economy how the market achieves many democratic values often asserted as justifications for broader governmental regulation. Part III extends the analysis to underground economic activity in the United States. Again, it cannot be claimed that all underground activities are morally justifiable and, no doubt, many will dispute the morality of particular types of underground activities, but the Essay will attempt to show that the broader condemnation of underground economies, however conventional, is highly problematic and cannot be defended.

7. See, e.g., MILTON FRIEDMAN, CAPITALISM AND FREEDOM (1962). 


\section{TWO EXAMPLES OF UNDERGROUND ECONOMIES AT WORK}

This Part describes the operation of underground economies in a centrally planned socialist state, the former Soviet Union, and in a Third World developing nation, Peru. The descriptions are not exhaustive and are meant only to illustrate major forms of underground economic activity. Examples were chosen from these countries because, given the nature of their respective governments, Western readers are less likely to condemn automatically the widespread contravention of the law that these underground activities display. ${ }^{8}$ Section A reviews the underground economy of the former Soviet Union, and Section $B$ reviews that of Peru. Section $C$ discusses similarities across these two very different economic cultures.

\section{A. The Underground Economy in a Centrally Planned State}

Prior to its fall in 1991, the Soviet Union (and, to a greater or lesser extent, its satellite countries) possessed a formal economy in which the state owned and controlled the means of production; made all resource allocation decisions; and prohibited a wide range of private economic activities, including the ownership of property and, in particular, private speculation. Notwithstanding these prohibitions, it was widely acknowledged that a substantial underground economy provided a broad range of goods and services to the Soviet citizenry.

\section{Agriculture}

The formal agricultural economy in the Soviet Union consisted of state farms and collective farms whose production decisions were largely subject to central control. State and collective farms were allocated all resources necessary for production, including land, machinery, seeds, fertilizer, and the like. In addition to this formal production, however, there existed a second agricultural economy, based upon private production entirely from small plots of land-adjoining or near to individual houses-that the state allocated to collective farm workers for their own production. These private plots were each quite small (on average, three-fourths of an acre), ${ }^{9}$ and they were farmed with the crudest of implements. ${ }^{10}$ In 1985 , these private plots constituted only

8. A review and evaluation of the underground economy in a Western capitalist country (the United States) are presented infra, Part III.

9. ZHORES A. MEDVEDEV, SOVIET AGRICULTURE 363 (1987).

10. Id. at 364-65. 
$1.4 \%$ of arable land in the Soviet Union, ${ }^{11}$ yet they accounted for extraordinary proportions of total Soviet agricultural production: $60 \%$ of potatoes; $29 \%$ of vegetables; $28 \%$ of meat; $29 \%$ of milk; $28 \%$ of eggs; and $26 \%$ percent of wool. ${ }^{12}$ Private production was virtually the only source for carrots, onions, garlic and other spices, tomatoes, beets, soft fruits, honey, and flowers. ${ }^{13}$ Private production supplied more than one-half of all food consumed by the rural population, and $90 \%$ of high quality food..$^{14}$

Private farming, of course, had been suppressed under Stalin, although authorities tolerated garden plots seemingly directed to self-consumption. ${ }^{15}$ The substantial second market developed because of shortages in production from state and collective farms. ${ }^{16}$ Indeed, when Brezhnev and Kosygin learned in the early 1960's of the disproportionate production generated by private plots, they relaxed the prohibitions on private farming. ${ }^{17}$ Over the years since, the state increasingly encouraged self-production of food. Gardening commissions have been organized to help citizens obtain farm implements, seeds, and fertilizer for private farming. ${ }^{18}$ The state also promoted private farming by industrial enterprises and even by the army. ${ }^{19}$ The state began to supply rural growers with transportation facilities to bring their excess produce to urban markets. Markets themselves, previously suppressed because they might enable speculation, were fostered, and their number increased rapidly. ${ }^{20}$ Finally, the state devised a theory that regarded private production as integral to "developed socialism."21 Subsidiary private agriculture was extolled as for its important role in the education of children as workers, instilling diligence, and influencing the development of values that consolidated the rural population. ${ }^{22}$

11. Id. at 364 tbl. 45 .

12. Id. at 366 tbl. 46. Similar data for 1979 are presented in F.J.M. Feldbrugge, The Soviet Second Economy in a Political and Legal Perspective, in THE UNDERGROUND ECONOMIES, supra note 5, at 311.

13. MEDVEDEV, supra note 9 , at 366.

14. Id. at 365 . There are similar reports in other Eastem European countries. In Hungary, for example, Gabor reports that the second economy produced an agricultural production value $10 \%$ greater than the formal economy. Istvan R. Gabor, Second Economy and Socialism: The Hungarian Experience, in THE UNDERGROUND ECONOMIES, supra note 5, at 339, 353.

15. MEDVEDEV, supra note 9, at 362-63.

16. Id. at 361 .

17. Id.

18. Boris Rumer, The "Second" Agriculture in the USSR, 33 SovIET STUD. 560, 564 (1981). It was also a common practice for workers on collective farms to carry off such supplies. Feldbrugge, supra note 12 , at 313.

19. Rumer, supra note 18 , at $563,566-68$.

20. Id. at 565 .

21. Id. at 563 .

22. V. Nefedov, Razvitiye Podsobnykh Khozyaistw, 11 VOPROSY ECONOMIKI 56, quoted in MEDVEDEV, supra note 9, at 367. 


\section{Housing and Home Repair}

There was no official private ownership of homes in the Soviet Union, ${ }^{23}$ but it was estimated that one-half of the Soviet population and one-fourth of the Soviet urban population lived in privately constructed and owned housing. ${ }^{24}$ In 1975 , nonstate construction entities completed thirty percent of all new housing space, often with materials acquired on the black market. ${ }^{25}$ The rental of housing was formally prohibited as a form of speculation but was quite common, especially in holiday resorts and cities. ${ }^{26}$

Construction work itself was a state enterprise, but increasingly common were groups of private tradespeople who travelled to places around the country where labor was short, selling their services at private market prices. ${ }^{27}$ In one province during the early 1980 's, these private workers-called shabashniki (sabbath workers, because they were willing to work on the sabbath)-completed 50\% more than state construction enterprises over the same period. ${ }^{28}$ Home repair was dominated even more heavily by the second economy. Estimates of the market share of private home repair and decoration reached $70 \%$ in Moscow and 99\% in rural areas such as Georgia. ${ }^{29}$

\section{Information and Cultural Products}

Although the Soviet state controlled the publication of books and other media, a substantial black market existed, particularly in Soviet-made, as opposed to foreign-produced, books. This market arose because the state's production plan provided for vastly insufficient numbers of books, especially the classics, given the demands of the citizenry. ${ }^{30}$ This particular shortage created a form of higher social status for speculation in classical works: According to one participant, "The resale of blue jeans is considered . . . rather 'déclassé'. Speculation in Herodotus-that is the mark of success." 31

23. Rights of occupancy were recognized, however. Gregory Grossman, The "Second Economy" of the USSR, PROBLEMS OF COMMUNISM, Sept.-Oct. 1977, at 25, 26.

24. Id. Gabor estimates for Hungary that one-half of the houses built each year and $80 \%$ of those in villages are built privately. Gabor, supra note 14 , at 354 .

25. Grossman, supra note 23 , at 26.

26. Dennis O'Hearn, The Consumer Second Economy: Size and Effects, 32 SoVIET STUD. 218, 225 (1980); Grossman, supra note 23, at 26.

27. O'Hearn, supra note 26, at 25; Feldbrugge, supra note 12, at 308.

28. Feldbrugge, supra note 12 , at 308.

29. O'Hearn, supra note 26 , at 225-26. Gabor estimates for Hungary that over $83 \%$ of home repair services are provided privately. Gabor, supra note 14 , at 355.

30. O'Hearn, supra note 26 , at 223.

31. Id. Comparisons of official prices to black market prices show Herodotus selling for three times the official price; George Sand at eighteen times; Dumas at fifteen times; and many authors, European and Russian, not available at all except on the black market. Id. at 224 tbl. 1. 
There are similar examples for other products. One observer reports that private vendors of video recordings offered 10,000 titles; the state store, only $1000 .^{32}$ In the early 1980 's, a thriving private market for phonograph recordings developed, supplied by a substantial underground record production industry. ${ }^{33}$ From 1 to 2.5 million recordings were produced each year from private recording studios. ${ }^{34}$ As might be expected, the production of other information products such as posters-especially political posters-was entirely private..$^{35}$

\section{Other Products and Services ${ }^{36}$}

\section{a. Hunting and Furs, Fishing}

The hunting and fur trapping industries were dominated by private production. Approximately $80 \%$ of muskrat yields (chiefly used for hats) derived from private sources. ${ }^{37}$ Because of the higher relative quality of the privately harvested yield, it accounted for $94 \%$ of total muskrat fur expenditures. ${ }^{38}$ Sixty-one percent of expenditures on fish were to black market sources. ${ }^{39}$

\section{b. Medical Services}

Medicines and the services of surgeons, physicians, nurses, and other medical personnel (otherwise freely provided by the state) provided an active black market because of pervasive shortages in state supplies. ${ }^{40}$ Illegal abortions, which necessarily involved private providers of medical services, numbered four to eight million each year. ${ }^{41}$

32. HEDRICK SMITH, THE NEW RUSSIANS 266 (1990).

33. O'Hearn, supra note 26 , at 224.

34. Id.; see also Feldbrugge, supra note 12, at 323.

35. Feldbrugge, supra note 12 , at 326 n.63.

36. Kornai reports that, in Hungary, the most common forms of underground activity are repair jobs including auto, home, and appliance repair, and domestic services. János Kornai, Some Lessons from the Hungarian Experience for Chinese Reformers, in MARKET REFORMS IN SOCIALIST SOCIETIES: COMPARING China And Hungary 75, 91 (Peter Van Ness ed., 1989).

37. O'Hearn, supra note 26 , at 223.

38. Id. at 226-27.

39. Id. at 226.

40. Grossman, supra note 23 , at 32 n.28.

41. Nikolai Shmelev \& Vladimir Popov, The TuRning Point: Revitalizing the Soviet ECONOMY 198-99 (1989). 


\section{c. Petroleum for Autos}

Because the state subsidized gasoline at exceptionally low prices, there were chronic shortages. Reports estimate that $80 \%$ of gasoline used in private automobiles in Kazakhstan and almost $87 \%$ in Omsk came from black market purchases. ${ }^{42}$ Virtually all of the black market supply was stolen from governmental sources. ${ }^{43}$

\section{d. Spare Parts}

Most spare part supplies-for machinery as well as appliances-had to be obtained on the black market. ${ }^{44}$ Indeed, specific shortages created unusual markets. As an example, in many cities, markets flourished for jam jar lids. ${ }^{45}$

\section{The Underground Economy and the State Bureaucracy}

Although underground economic activities were formally prohibited by the state, state officers were in fact often substantially involved in underground activities. In some cases, this involvement served to further the nominal objectives of the state. In other instances, the objectives appear to have been purely personal to the state officer-corruption-although the distinction was not always clear.

\section{a. Diversion to Increase State Productivity}

Enterprise managers often diverted supplies from intended uses and bartered them to obtain other supplies necessary to meet enterprise production goals or to improve employee morale. ${ }^{46}$ Here, either because of a shortage in necessary supplies or their delay in arrival, managers evaded the strict requirements of controllers in order to better achieve the goals the controllers had set for them.

\section{b. Allocation of Government-Provided Products}

Although the prices of government products sold at state stores were strictly controlled, it was apparently a widespread and well-established practice

42. O'Hearn, supra note 26 , at 221 .

43. Feldbrugge, supra note 12, at 303.

44. Id. at 322 .

45. Id. at 325 n. 60 .

46. See Grossman, supra note 23 , at 30 . 
for employee vendors to set aside preferred products or those in greatest shortage for specific patrons, who would reward the salesperson with a tip or "gift." The tip was usually split between the salesperson and the next-higher supervisor and then split again, repeatedly, up the salesforce hierarchy. ${ }^{47}$

The state bureaucracy took advantage of shortages in consumer goods in a different way, by institutionalizing a form of government privilege to serve as a bureaucratic incentive. Government workers could earn "certificate rubles," rewards expressed in terms of rubles but exchangeable only in special stores that sold very scarce consumer products at subsidized low prices. ${ }^{48}$ Prior to their abolition in 1975, certificate rubles sold on the black market at six to eight times their face value. ${ }^{49}$

\section{c. Bribes}

Direct bribes in the form of money or goods were widely used to secure such official forms of authorization as a driver's license, a permit to buy a car, an allocation of living space, a residential building permit, and admittance to an educational institution. ${ }^{50}$ Through bribery, people also obtained passing grades on examinations and doctors' certificates that allowed them to stay home from work. ${ }^{51}$

\section{d. The Existence of the Black Market as a Recruitment Device}

One of the great attractions of government service was that it provided extensive opportunities to travel abroad. ${ }^{52}$ Beyond simple enjoyment, travel enabled a government officer to buy domestically unavailable products, either for personal consumption or for conversion on financially attractive terms on the domestic black market. ${ }^{53}$ In addition, a government position would generally insulate a citizen from prosecution for participation in illegal economic activities. ${ }^{54}$ Alexander Yakovlev, a Gorbachev ally who had run the Propaganda Department of the Communist Party during the 1970's, put the matter more sharply: "[T]he 'shadow economy' in our country is not

\footnotetext{
47. Id.

48. O'Hearn, supra note 26, at 228; Feldbrugge, supra note 12, at 332.

49. O'Hearn, supra note 26 , at 228.

50. Feldbrugge, supra note 12 , at 322 .

51. Id. at 322 n.53.

52. Id. at 332 .

53. Id.

54. Id. at 334 .
} 
something that exists alongside the 'lawful economy.' It is the official economy but is used by officials for their own interests.".55

\section{B. The Informal Economy of a Developing Nation}

Peru can be characterized formally as a capitalist, free market country, in which governmental activities resemble those of typical Western welfare states. According to descriptions in a recent book by Hernando de Soto, however, Peru's legal system consists of a regulatory bureaucracy which exerts substantial control on developing enterprise through a tightly administered system of permits and authorizations. ${ }^{56}$ De Soto sought to determine and quantify the costs of initiating various forms of commercial enterprise in Peru. $\mathrm{He}$ and his researchers found that full compliance with the laws and regulations of Peru would require eighty-three months to obtain a permit to build housing on state-owned waste land; ten months, at a cost equal to thirtytwo times the monthly minimum wage, to start a business; forty-three days to open a retail store; seventeen years to open a market; and twenty-seven months to gain an otherwise unused transport concession. ${ }^{57}$ These costs of proceeding through official governmental channels are obviously substantial. According to de Soto, they have given rise to a large informal economy operating nominally outside the law.

\section{Informal Housing}

Between 1940 and 1981, the urban population of Peru increased from 2.4 to 11.6 million people. ${ }^{58}$ The largest share of this increase resulted from mass migration from the countryside to the cities. ${ }^{59}$ The existing urban housing stock was insufficient to handle the migration, especially since the majority of immigrants were very poor.

These conditions led to the spread of what de Soto calls "informal housing." ${ }^{160}$ Informal housing consists of settlements of dwellers who neither own the land upon which they have built, nor obtain certifications of compliance with existing building and sanitation codes. These settlements are

55. AleXANDER YakovleV, The FATE OF MARXISM IN RuSSIA 112 (Catherine A. Fitzpatrick trans., 1993) (alteration in original).

56. The Peruvian discussion here derives entirely from HERNANDO DE SOTO, THE OTHER PATH (1989).

57. Id. at 133-46. De Soto's group decided to pay bribes to officials to accelerate the process only if absolutely required. Id. at 134 . They were solicited frequently, but were obliged to pay bribes only twice during the study. Id. at xiv.

58. Id. at 7 .

59. Id.

60. Id. at 17-57. 
initiated by an organized "invasion" of unused land. Typically, but not always, the invaded land belongs to the state. When an invasion is successful-which is to say, not resisted by the police-the dwellers proceed to distribute plots and, anticipating no formal government support, form a civic organization to establish and enforce rules of conduct within the settlement.

Although it is possible under Peruvian law for an informal settlement to attain official and formal status, including title, de Soto estimates that the achievement of full formality would require 159 separate governmental authorizations and take approximately twenty years. The unwillingness of the police to evict, however, provides some degree of security, a security enhanced as time passes and further investments in the settlement are made.

Lack of formal authorization, however, has not discouraged private investment in informal settlements. Studying the informal settlements in existence in 1982, de Soto and his group estimated that the average value of a home in an informal settlement in Lima was $\$ 22,038$, and the total value of informal housing in Lima was equal to $\$ 8.32$ billion, all the result of private investment. In contrast, during the period of mass informal settlement, 1960 to 1984 , the Peruvian government, though seemingly dedicated to social reform, invested only $\$ 173.6$ million in public housing, equal to $2.1 \%$ of informal investment. ${ }^{61}$ In 1982, the housing stock of Lima, according to de Soto, was $42.6 \%$ informal, $49.2 \%$ formal, and $8.2 \%$ slum areas. ${ }^{62}$

\section{Informal Trade ${ }^{63}$}

De Soto identifies as informal trade the collection of sales by street vendors, with and without permanent locations, as well as sales in stalls in established markets. This trade is informal because it proceeds without government permits, receipts records, or tax payments.

De Soto's group found that in 1986 there were 91,455 street vendors in Lima. Eighty percent of the vendors operated in districts regarded as lowincome neighborhoods. Roughly $60 \%$ sold foodstuffs; $18 \%$ sold personal accessories; $14 \%$ sold services; and $9 \%$ sold household and office supplies. Fifty-four percent of the vendors were women. ${ }^{64}$

Because these vendors operated outside formal law, rights of ownership to locations were not certain, but were enforced to some extent within vendor groups and associations. These associations also provided mutual policing and self-defense from thieves as well as other invading vendors. Some degree of

61. Id. at 18.

62. Id.

63. This description is taken from id. at 59-92.

64. Id. at 60 . 
property protection resulted. De Soto learned of the sale of the rights to a three-square-meter location for a particular period of the day near a central plaza for as much as $\$ 1000 .{ }^{65}$ De Soto's group estimated that street vending provided employment for 314,000 people and generated sales of $\$ 322.2$ million per year. ${ }^{66}$

Informal markets consist of groups of stalls established in central locations and were preferred by vendors wanting to leave the streets. Although the government established formal markets-that is, with permits-from 1965 to 1985, the creation of informal markets outstripped the formal by a twelve-toone ratio. De Soto's group identified 239 separate informal markets, more than half of which were located in informal settlements. The group estimated that these markets provided employment for 38,897 people. $^{67}$

\section{Informal Transport ${ }^{68}$}

Informal transport consists of a collection of privately owned sedans, station wagons, vans, and buses, whose chief occupation is to meet the transportation needs of residents of informal settlements. These enterprises are informal because they proceed without permits and, as a consequence, without the benefits that come with formal status, including resort to contract law, limited liability, credit, and insurance. According to de Soto, during the period of study, $91 \%$ of all public transit vehicles in Lima were informal. ${ }^{69}$

Informal transport operations were successful if they could establish a custom appropriate for their scale and could guarantee regular service. They operated with much greater flexibility than typical public transit operations, often traversing specific routes with particular points of pick-up and drop-off convenient to individual riders. While it was impossible to gain rights to particular routes, operators did form organizations that attempted to police agreements, mediate disputes, and provide related services (including credit, in some cases) to facilitate mutual benefit. De Soto's group estimated that the replacement value of the capital stock of informal transport in Lima equalled $\$ 620$ million, with an additional $\$ 400$ million invested in supportive services. $^{70}$

65. Id. at 68 .

66. Id. at 60 .

67. Id. at 61 .

68. The description of informal transport is taken from id. at 93-127.

69. Id. at 93 .

70. Id. 


\section{Some Lessons from the Underground Experience}

Although the activities of the second economy of the former Soviet Union and of the informal economy of Peru appear to be very different, there are substantial similarities among them in terms of their sources and effects. First, much of the underground activity derives from the failure of the government or other institutions of society to provide goods and services responsive to the demands of its citizenry. Where government control is unable or unwilling to provide goods, the market-necessarily in the Soviet Union, an underground market-responds. It is well known that there were chronic shortages of food, consumer goods, and services in the Soviet Union. As Yakovlev, the former propaganda minister, put it, "For decades, cast iron, coal, steel, and petroleum had priority over food, housing, hospitals, schools, and services."71 The second economy arose to partially replenish shortages in such areas as agriculture, housing, and even books and jam jar lids. According to Boris Rumer, for instance, the second agricultural economy was able to "substantially counteract the deepening food crisis in the country." In such contexts, in which the magnitude of the state's failure was sufficiently large, the state began to embrace and even promote the second economy.

The Peruvian informal economy, similarly, arose to satisfy unfulfilled demands. Constrained by governmental regulations that made acquiring urban land and housing virtually impossible through formal, legal means, the Peruvian informals created settlements through squatting and private investment. As de Soto reports, informal housing investments vastly exceeded government investments in housing over the same period. The experience with informal transport and trade is similar. Private buses and vans filled routes not serviced by public transportation. Burgeoning private markets and street vendors vastly expanded the range of items-chiefly low-priced items-available for purchase along public thoroughfares.

The employment of the black market in the Soviet Union as an incentive for bureaucrats themselves may illustrate a related effect: the use of the underground economy to achieve ends that are frustrated by prevailing regulation. It is difficult in some cases to distinguish between bureaucratic involvement in the black market as a technique for enhancing bureaucratic production, and bureaucratic involvement that represents simply a corrupt exploitation of power. Yet, there are certainly instances in which reliance on the black market enhanced the ability of government officers to satisfy planning needs, for example, where supplies were bartered (rather than

71. Yakovlev, supra note 55, at 74 .

72. Rumer, supra note 19 , at 560. 
allocated according to planning directives) in order to accelerate deliveries. In addition, government officers' relative freedom to travel abroad where they could purchase goods, and their relative insulation from prosecution for black market participation may have served as a means to recruit relatively more able individuals to the bureaucracy than would otherwise choose to serve. Moreover, even if the channeling of special goods to government officers or their obtaining them on the black market is regarded as corrupt, both represent a further example of the market providing goods insufficiently provided by the government. Bureaucrats, no less than private citizens, possess demands which, if not satisfied by government production, will generate opportunities for a black market or underground economic activity.

The underground economies have had similar effects in the Soviet and Peruvian societies, in that both clearly increased the wealth of those societies. This increase is illustrated by de Soto's estimates of housing settlements worth billions of dollars and markets generating hundreds of millions of dollars in annual sales. The Peruvian experience parallels the second Soviet agricultural economy, which produced thirty to sixty percent of aggregate foodstuffs. Besides increasing wealth, underground economies (like formal markets) improve the allocation of societal resources. Examples include the conversion of what de Soto calls government waste land into urban neighborhoods of substantial value, ${ }^{73}$ and the achievement of extraordinary agricultural yields from less than two percent of Soviet arable land.

The contributions of these underground economies to society, however, are not merely financial. The Soviet black market facilitated the distribution and sale of books, recordings, and videos. Soviet officials themselves extolled the second agricultural economy as instilling an important work ethic in children and encouraging initiative. This is not to say that the underground market serves as a complete moral tutor of the citizenry. Like any formal market, it can only be responsive to the demands of the citizenry. But the existence of the underground economy reflects, by definition, a response to citizen demands unfulfilled by government.

Finally, the underground economy has important implications for the issue of income distribution. As the Peruvian examples show, informal economic activity vastly increases the well-being of the poorest among the population. The informal economy represents efforts to meet housing, transport, and trade needs that would otherwise be unmet. The difference in Peru between government investment in housing for the poor ( $\$ 173.6$ million) and private investment ( $\$ 8.32$ billion) suggests the power of underground economic

73. I ignore the fact that the conversion was achieved through theft, though I discuss the moral defense of government policies and citizens' responses to them infra, Part II. 
activity to promote the welfare of the least well-off. ${ }^{74}$ The Soviet examples are largely similar. Many of the services in the second Soviet economy are those typically provided by individuals with less skill and lower incomes, such as hunting, fishing, and home and appliance repair. The various Soviet reports also document relatively greater levels of underground activity (homebuilding, for example) in rural areas and provinces, away from more industrialized cities. $^{75}$

Generally, underground economies provide comparatively greater opportunities for women and other groups traditionally subject to discrimination. Sampson reports that many entrepreneurs within the underground Soviet economy were "Armenians, Georgians, or Jews who have been denied avenues of social mobility in the normal hierarchies of science, arts, the army, or the party." ${ }^{176}$ In both Peru and the former Soviet Union, the underground economy provides relatively greater opportunities for women to participate in the labor force than does the formal economy. ${ }^{77}$ Beyond the Soviet and Peruvian examples, Lever reports an underground economy dominated by women in Spain. ${ }^{78}$ And, in a more general review of informal economies worldwide, Portes and Böröcz conclude that "members of discriminated ethnic and racial groups tend to be overrepresented as workers in informal enterprises.... The existence of socially ascribed negative stereotypes of a particular group facilitates their willingness to accept unprotected and poorly paid work in general, thus propelling them towards informality."79

\section{THE MARKET Versus the StATE AS A MEChANISM OF ECONOMIC ORGANIZATION: A CONCEPTUAL APPROACH TO THE EVALUATION OF THE UNDERGROUND ECONOMIES}

We have identified the principal contributions of underground economies to the societies within which they operate as wealth creation, superior resource allocation, and an increase in economic opportunities for the poor and other

74. Participants in the underground economy, of course, proceed without the benefit of safety regulation and other governmental controls. Whether these governmental policies constitute true "protections" of the poor is addressed infra, Part III.

75. Grossman, supra note 23, at 34 (rural Georgia); Feldbrugge, supra note 12, at 308-09 (rural Georgia).

76. Steven Sampson, "May You Live Only by Your Salary!": The Unplanned Economy in Eastern Europe, 15 Soc. JUST., Fall-Winter 1988, at 148.

77. Alejandro Portes \& Jozsef Böröcz, The Informal Sector under Capitalism and State Socialism: A Preliminary Comparison, 15 Soc. JUST., Fall-Winter 1988, at 22; de Soto, supra note 56, at 60.

78. Alison Lever, Women's Employment in the Informal Sector: San Santiago, Spain, 15 Soc. JuST., Fall-Winter 1988, at 87.

79. Portes \& Böröcz, supra note 77 , at $21-22$. 
victims of discrimination. These contributions are features of all markets, whether underground or formal, and reflect the differential capacities of markets to politics, as mechanisms for directing economic activity. Traditional comparisons of the market to political organization have conceded the superiority of the market in terms of both wealth creation and the maximization of individual liberty, ${ }^{80}$ but have criticized the market not only for what are typically referred to as "market failures" but also for the inability of the market to achieve "higher" societal goals purportedly only attainable through political action. ${ }^{81}$ As we shall see, examples from the underground economies suggest that the moral justification of the marketplace is substantially broader.

Politics and the market can be regarded as alternative means of aggregating the preferences or demands of the citizenry with respect to the disposition of resources available to the society. The government of a society, regardless of the form of political organization, derives from and, to some extent, is responsive to the demands of its citizens regarding the allocation of resources. The "government" and the actions it takes to control economic activity represent only the result, the expression, of some aggregation of citizens' preferences effected according to the rules and procedures of the political organization of the society.

The market, similarly, is a mechanism for aggregating citizens' demands. Necessarily reliant upon some prior definition of property rights, the market, in contrast to the state, operates through the interactions of individual citizens by means of trade or exchange. The aggregation of these interactions, too, results in an allocation of societal resources.

The metaphor that Adam Smith chose to illustrate the operation of the market and its difference from the state-the metaphor of the "invisible hand"-is misdescriptive in this regard. The operation of an invisible hand aptly captures Smith's important point that the seemingly uncoordinated actions of thousands of separate individuals can generate a coherent and defensible allocation of resources. But the contrast between an invisible hand of the market and a visible hand of government is misleading. Perhaps the monarchy of Smith's time or, say, a totalitarian regime such as Stalin's might appropriately be described as operating in the manner of a visible hand. But in the more complicated regimes of modern times-even totalitarian regimes and surely, modern democracies-a metaphor suggesting a government directed by a single hand is misplaced. The transformation of individual

80. See, e.g., FRIEDMAN, supra note 7; FRIEDRICH A. HAYEK, THE ROAD TO SERFDOM (1944).

81. See Ronald Dworkin, Is Wealth a Value?, 9 J. LEG. STUDIES 191 (1980); Anthony T. Kronman, Wealth Maximization as a Normative Principle, 9 J. LEG. STUDIES 227 (1980). 
consumer preferences to an allocation of resources through the marketplace is no more invisible than the transformation of individual citizens' political preferences into government allocation decisions through the political organization of the state.

Of course, there will be differences between the resultant allocation of resources through the mechanism of the market and through the mechanism of a state's political organization. ${ }^{82}$ Differences in outcome will derive from differences in the operative mechanisms themselves. The respective mechanisms of politics and the market are controlled by different rules and procedures and will predictably generate different results. ${ }^{83}$

In addition, as has been traditionally emphasized to some extent, the domain of politics and the market are different. There is no "market" for, say, justice or civil virtue comparable to the effort to achieve these goals through political action. This difference, however, is often overemphasized. No one can deny that a broad range of political action-indeed, perhaps the broadest range-operates solely to control economic activity and to allocate society's resources.

The underground economy provides a critical and underappreciated picture of the differences between the operation of politics and the market. Whatever the form of political organization, the underground economy reflects the conflict between the market and politics as mechanisms for satisfying the desires of the citizenry with respect to the allocation of resources. Where political controls prevent or constrain the satisfaction of citizen needs, a demand for their satisfaction will arise, generating incentives for the creation of a market. Because of government policies, this market necessarily must operate underground.

A totalitarian government, such as that of the former Soviet Union, may generate outcomes that deviate substantially from the desires of many citizens. Similarly, a bureaucracy dominated by a plutocracy, as in Peru, may well generate outcomes that are largely insensitive to the desires and interests of many, including the poor. In societies of this nature, it is not surprising that large underground economies arise. As the earlier examples suggested, these underground economies generate a supply of products and services that have been provided in insufficient quantity or quality by the governments themselves. Indeed, the greater the deviation between the desires and demands of the citizenry and the products and services either produced by the government (as in the Soviet Union) or authorized by the government (as in

82. For a different discussion of this point, see JAMES BuCHANAN, LIBERTY, MARKET AND STATE (1985).

83. This is the principal subject of the public choice literature. 
Peru), the larger one would expect the magnitude of underground economic activity to be.

One might think that the existing underground economy in any society could never represent exhaustive evidence of the conflict between aggregation by means of political organization and aggregation by the market, because a government's prohibition imposes costs that will suppress underground economic activity to some extent. For example, if state enforcement were sufficiently severe, underground economic activity may be negligible. The level of government enforcement, however, will itself derive from some aggregation of citizens' preferences expressed through the political process. Thus, where government prohibitions of underground activity are severe, citizens' preferences for such prohibitions must be of substantial magnitude. Conversely, the second agricultural economy in the Soviet Union suggests that the size of the underground economy correlates directly with the demands of the citizenry. When demand is great, the state may be forced to embrace the underground economy rather than continue to prohibit it.

As a consequence, except for those imaginary societies whose political systems are perfectly responsive to citizens' desires, we can expect to observe underground economies universally. These underground economies will be of different dimensions, determined by the success or failure of the political organization of the state to respond to the preferences or demands of individual citizens. As the political organization of a state is more effectively responsive to the preferences of its citizens, the alternative mechanism for the expression of citizens' demands-the market, though an underground economy-will be relatively small. In contrast, where the deviation of politics from the demands of citizens is great, the alternative-the underground economy-will assume substantial proportions.

It is important here to distinguish between the preferences and demands of the "citizenry" viewed in some aggregate form, and the preferences and demands of individual citizens or of some group of citizens. In an ideal world, one might want a government to be responsive to each and every citizen as well as to all groups of citizens, however small. Such an ideal is unrealistic, however, not only in practical terms, but because the demands of different citizens expressed in political terms often conflict. The conflicting demands of citizens are less likely to be resolved to the satisfaction of all parties through politics than through a market if only because there is no political "currency" equivalent to money in its capacity to register and then mediate differential intensities of citizens' desires. The demands of those citizens outmuscled in the political arena will provide the source for an underground economy.

For these reasons, it should not be surprising to discover the existence of underground economies even in societies with political organizations that differ 
substantially from the totalitarian or plutocratic states reviewed above. Indeed, the substantial literature on the political organization of democratic states can explain the existence of underground economies even in what seem to be the most open and least regulated societies. As is well known, the market and a democracy sharply differ in terms of the respective mechanisms for the aggregation of citizens' preferences. The market operates by registering citizens' preferences as expressed in terms of willingness to pay. A currency, money, allows different intensities of preferences to be expressed in perfect detail. A democracy, in contrast, registers preferences of the citizenry through the ballot. In a democracy, each citizen's vote is accorded equal weight. In all democracies, however, only a limited number of citizens participate by voting.

These differences suggest a well-known set of problems in registering citizens' preferences associated with markets and democracies, respectively. Markets may fail to reflect the true preferences of the citizenry for reasons of monopoly, externalities, the existence of public goods, and income maldistribution. Democracies, on the other hand, may suffer problems of aggregation in the definition of social welfare where votes are treated equally, rather than weighted according to intensity of preference, leading to cycling among voter preferences and the absence of stable equilibria. ${ }^{84}$ Democracies are vulnerable to the control of special interests and voting blocs, because of the resulting advantages of logrolling and because of limited participation in the ballot. ${ }^{85}$ In addition, because, according to the pure theory of democracy, the jurisdictional limits of different democratic political entities-cities, counties, districts, states-are essentially arbitrary, the preferences of certain groups of citizens may predominate differentially. Markets, in contrast, though requiring some minimum scale of operations to be sustainable, can still be responsive to preferences of very small numbers of citizens, and surely to those with insufficient strength to command political attention.

To view the market and politics as no more than alternative mechanisms for the aggregation of citizens' desires, however, puts into question the conventional moral condemnation of the underground economies. There has been a strong tradition in Western political thought to enshrine political action as encompassing some inherently superior moral virtue in comparison to activity in the marketplace. It follows from this tradition that any contravention

84. See KenNeth J. ARrow, Social Cholce and Individual Values (2d ed. 1963). To simplify Arrow's argument, if, among three policy alternatives, Voter 1 prefers policy $A$ to $B$ to $C$; Voter 2, B to $\mathrm{C}$ to $\mathrm{A}$; and Voter $3, \mathrm{C}$ to $\mathrm{A}$ to $\mathrm{B}$; in the absence of the ability to register the relative intensity of these preferences (i.e., where, unlike in a market, each "vote" is weighted equally), there will be no stable equilibrium over successive rounds of voting. For a more general discussion of the problems in the aggregation of preferences in a democratic state, see generally DENNIS C. MUELLER, PUBLIC CHOICE II (1989).

85. See generally Mueller, supra note 84 . 
of formally approved rules or regulations constitutes a violation of this moral value ${ }^{86}$ The statist approach to the problem, however, must be reexamined.

The evaluation of politics versus the market in moral terms has tended to be dominated by a view that emphasizes nonmaterial or noneconomic goals and values-such as justice or community-differentially attainable through politics. This paper is not the occasion to debate the point at length, but even conceding these examples, the presumption of the moral superiority of politics cannot be equally extended to the control of economic activity. In addition, the moral superiority of political action has been defended, especially in Western democracies, on the grounds of the essential equality of citizens in the voting booth, in contrast to the marketplace. ${ }^{87}$ The desire for greater equality of income or wealth stems from the view that, on moral grounds, citizens should be equal, rather than differentiated according to success in the market.

The moral defense of the market and, by extension, of underground economies, has been far less well developed. To canvass the moral landscape briefly, however, markets promote many important societal values. There is wide agreement that, given appropriate controls on monopoly and externalities and appropriate investment in public goods, the market is superior to political control as a means of societal wealth creation. In addition, putting aside (for now) questions of income distribution, it is widely accepted that the market is superior to political control as a mechanism for societal resource allocation. In both respects, because of problems of vote aggregation and the influence of special interests, regulation by political entities diverts the economy, reducing wealth and misallocating societal resources. ${ }^{88}$ This, of course, is the vivid lesson of the former Soviet and Eastern European economies, though I would suspect that most would subscribe to the proposition more generally. In addition, the moral justification of the market in terms of its maximization of individual liberty is well known. ${ }^{89}$

The operation of the marketplace, however, promotes many other moral values that are often neglected in traditional discussions. For example, with respect to income distribution, a preference for income equality may surely be defended, but such a defense must address the moral basis justifying the distribution of rewards by the marketplace. Many individuals, including some who staunchly defend the market on grounds of personal liberty, find it difficult to defend on moral grounds the way in which the market rewards its

86. As an example of this approach, see the judgments of Professor Feige, supra text accompanying notes 3-5.

87. See Dworkin, supra note 81 .

88. Again, I except the control of monopolies and externalities, and the provision of public goods.

89. See FRIEDMAN, supra note 7; ROBERT NOZICK, ANARCHY, STATE AND UTOPIA (1974); Richard A. Epstein, The Moral and Practical Dilemmas of the Underground Economy, 103 YALE L.J. 2157 (1994). 
participants. Hayek, for example, viewed the distribution of income and wealth from market activities as largely fortuitous. ${ }^{90}$ Others go further and associate market success with undesirable personal characteristics, such as greed ${ }^{91}$ or, following Adam Smith, self-interest. Few have suggested that market rewards bear any relation to a distribution that can be regarded as just.

There is a powerful consequentialist moral justification, however, for the distribution of market incomes. The marketplace distributes rewards according to the level of benefits provided to other individuals-consumers. ${ }^{92}$ A citizen is rewarded through the market exactly to the extent that that citizen has created a product, added value to it, or provided a service of benefit to someone else. Hayek viewed the shifting of profit opportunities in response to changes in supply and demand as fortuitous, and it is from the standpoint of the participant who, in a competitive market, cannot influence price. From the standpoint of consumer beneficiaries, however, differential rewards in response to changes in supply and demand are well deserved, since the market price reflects the benefit conferred upon consumers. Indeed, better than any other imaginable measure of desert, the market provides rewards according to genuine evaluations of the level of benefit provided, as the beneficiary personally indicates value and consents to receive it by voluntary payment for the product or service.

This is necessarily a consequentialist definition of a moral or just distribution of rewards. Most moral criticisms of the market have derived from the Kantian focus on the intention of the participant, and have largely accepted Adam Smith's characterization of markets motivated by self-interest. A full discussion of this question is beyond the scope of this Essay. Viewed differently, however, as a system for the distribution of rewards, the level of self-interest of a market participant is of no general importance because, under a system of laws, greed does not correlate with productivity. ${ }^{93}$ The beneficiary of market activities-the consumer-cannot distinguish a monster of greed in a competitive market from an altruist willing to sell a product at bare cost. As a system, the market distributes rewards as might God in the afterlife: according to the level of benefits conferred on others.

90. See 2 F.A. HAYEK, LAW, LEGISLATION AND LIBERTY 126-28 (1976).

91. Stuart Henry, Can the Hidden Economy Be Revolutionary? Toward a Dialectical Analysis of the Relations Between Formal and Informal Economies, Soc. JuST., Fall-Winter 1988, at 29.

92. See John B. Clark, The Distribution of WeAlTh (1914). For a less developed version of this approach, and different because of its advocacy of market simulation through judicial decisionmaking, rather than genuine market activity itself, see RICHARD A. POSNER, THE ECONOMICS OF JUSTICE 48-115 (1981).

93. This point is important for the evaluation of the moral justification of underground economic activity. See infra pp. 2281-82, 2284-85. 
The recognition of the market and politics as alternative mechanisms for the aggregation and expression of citizens' desires also suggests another moral defense of the market in contrast to politics, here on noninstrumental grounds. For example, the Kantian values of autonomy and respect for the person are often invoked in defense of the democratic principle of the equally weighted ballot, ${ }^{94}$ especially in contrast with the market, in which individuals enter with differential abilities to pay. ${ }^{95}$ On the other hand, the outcomes of political action, except in rare cases of unanimity, necessarily entail the prevalence of desires of one set of citizens over another. The market, in contrast, and underground economic exchanges in particular, involve consensual transactions between participants, thus reflecting an aggregation of citizen preferences that is purely noncoercive. ${ }^{96}$

Finally, the underground economies provide substantial evidence of the success of the market in contrast to politics, in terms of promoting what might be called the Rawlsian value of protecting those least advantaged in society. ${ }^{97}$ The examples of the Soviet Union and Peru show that underground economies provide a mechanism for those without political influence to help themselves and, at the same time, to contribute to society by providing goods and services of benefit to others. Underground economies provide opportunities for those with low incomes and low skill levels, as well as those subjected to discrimination, to participate in the economy-participation otherwise denied them through the political process. Discrimination is often successfully implemented politically because a citizen can express a discriminatory preference without cost and because discrimination often provides a vivid ground for vote aggregation. It is substantially more difficult for a consumer to discriminate against producers of goods in the market, since their identities are generally unknown. It is not surprising, therefore, that the examples of the informal economy in Peru illustrate that the market created far greater wealth for the poor than did the social welfare governments that were politically dedicated to help them.

These various values promoted by the market:

1) wealth creation;

2) the superior allocation of resources;

3) the maximization of individual liberty;

4) the distribution of rewards according to benefits conferred;

94. See, e.g., ROBERT A. DAHL, DEMOCRACY AND ITS CRITICs 84-101 (1989). These values also support democratic protections of individual rights, though the protection of individual rights is in no way inconsistent with market activity.

95. See Dworkin, supra note 81 ; Kronman, supra, note 81 .

96. The point is suggested in POSNER, supra note 92. But cf. Jules Coleman, Efficiency, Utility, and Wealth Maximization, 8 HOFSTRA L. REV. 509 (1980).

97. JoHn RAWLS, A THEORY OF JUSTICE 14-15 (1971). 
5) respect for personal autonomy; and

6) the creation of opportunities for the poor;

are surely considerable. Of course, the universal prevalence of an institution such as the market might suggest that it promotes widely held societal values. Indeed, it is curious that there has not been more systematic appreciation of the market's role.

These moral foundations of the legitimate market, however, are different from the moral foundations of the underground economy. The legitimate market is not burdened with prohibitions derived from political action. Yet, except for asserting the superiority of the state, there are no a priori grounds for allowing the political prohibition itself to trump. Nevertheless, in the first instance, the political prohibition is surely evidence that some set of citizens believes that the underground activity diminishes societal welfare.

Some commentators, of course, defend underground economic activity on the basis of just one of the values listed above: the maximization of personal liberty. ${ }^{98}$ Such a position is surely defensible. Yet a broader defense can be raised. Among the wide range of activities lumped together under the "underground" category, those that promote all of the values of the market listed above-beyond merely the maximization of personal liberty-stand on the strongest moral foundation.

For purposes of such moral evaluation, it is helpful to distinguish between two sets of underground economic activities: first, those that represent merely pecuniary transfers from the government to the citizen; and, second, those that are related to increased productivity and that facilitate market exchange. This distinction will be more fully illustrated in the next Part but, as an example, an underground activity such as counterfeiting currency is very difficult to defend on grounds of the moral values promoted by the market. Counterfeiting has a redistributive effect only. It does not enhance national wealth; ignoring effects on the money supply, it has no positive effect on the allocation of resources; the gains to the participants do not derive from benefits conferred on others; and it does not systematically create opportunities for the poor. Some may defend the activity on grounds of minimizing interference with personal liberty, but the defense is not compelling.

In contrast, the various underground economic activities described above within the former Soviet Union and in Peru-for example, the second Soviet agricultural economy and informal activities in Peru-appear defensible largely because their effects are so different: they increase societal wealth; improve resource allocation; distribute rewards according to benefits conferred; and provide opportunities for the poor; in addition to enabling greater personal

98. See Epstein, supra note 89. 
freedom and respecting personal autonomy. Given these virtues, the activities are easily defended on moral grounds, regardless of their formal legal prohibition. Indeed, as we have seen, these virtues in many instances led even the respective states subsequently to embrace them.

The distinction I have drawn resembles the distinction in economics between productive and redistributive activities, although it is broader. No economic activity has effects that are solely redistributive: even thieves later spend the money they steal. In contrast, the distinction that I propose is between underground economic activities that stimulate market action-such as the second Soviet agricultural economy or informal housing or trade in Peru-and activities that merely make one set of individuals more wealthy at the expense of the state, which is to say, at the expense of all other citizens not participating in the underground activity.

\section{RECONCEPTUALIZING THE UNDERGROUND ECONOMY: THE MORAL FOUNDATIONS OF UNDERGROUND ACTIVITIES IN A DEMOCRATIC STATE}

It is straightforward to defend the underground economy in a totalitarian state such as the former Soviet Union, and even in a hyper-regulated state, as de Soto describes Peru. This Part addresses, though briefly, a more difficult question: Are there moral justifications for some set of underground economic activities within a democracy such as the United States?

Among the advanced nations, the United States possesses the most extensive and least regulated market economy. Recent studies indicate, however, that there is a substantial underground economy in the United States. ${ }^{99}$ As indicated earlier, a 1992 Department of Labor publication distinguishes among aspects of the underground economy in this country according to the following categories: illegal, unreported, unrecorded, and informal. ${ }^{100}$ The illegal sector comprises traffic in prohibited goods and services, such as prostitution, drugs, firearms, counterfeit currency, and loan sharking. The unreported sector consists principally of tax evasion, both of income taxes and of employment taxes and benefits. ${ }^{101}$ The unrecorded sector encompasses those activities that never reach the eye of statistical agencies in any way, distinguishing, for example, those who underpay taxes (unreported) from those who never file at all (unrecorded). Examples of unrecorded

99. Richard D. Porter \& Amanda S. Bayer, Monetary Perspective on Underground Economic Activity in the United States, in THE UNDERGROUND ECONOMIES, supra note 5, at 129, 129; DEP'T OF LABOR, supra note 1, at 9-26.

100. DEP'T OF LABOR, supra note 1 , at 4 .

101. Some of the activities that the publication categorizes as illegal, such as violations of liquor controls and smuggling, may be better understood as examples of tax evasion. Appropriate categorization, however, is not important to the study here. 
economic activities are farm and construction work, work "off-the-books," and various personal services. Finally, the informal sector-not sharply distinguished from the unrecorded-consists of work violative of some prohibition, though not illegal in itself: in particular, domestic or factory work by illegal immigrants, and the like. These categorizations are not watertight, but that is unimportant for this study. The Department of Labor report presents estimates of the size of the aggregate underground economy from $\$ 42$ billion to $\$ 1.096$ trillion. ${ }^{102}$ Is there a moral justification for any of these underground economic activities?

\section{A. The Illegal Economy}

The moral defensibility of an illegal economy in a democratic state is different from the moral defensibility of the activities-for example, prostitution and drugs-that constitute that economy. Many people-myself included-condemn drug use and prostitution in the sense of making a personal moral judgment never to engage in such activities. It is a different matter to conclude that the state should employ its force to prohibit all citizens from engaging in such activities.

The existence of an underground economy in these activities, of course, is definitive evidence that not all citizens share this moral judgment. Besides participants themselves, some libertarians support the legalization of these activities on grounds of maximizing liberty and respecting the personal autonomy of equal citizens. Though much more careful attention should be given to the topic, it is possible that the broader moral values of the market would also support legalization. Whatever one's moral feelings, prostitution and the drug trade involve transactions that are more or less voluntary, ${ }^{103}$ between citizens who believe the transaction will benefit their lives. Tangible external effects-except those, like violence, that derive from the prohibition itself-are modest. Rewards are distributed according to benefits conferred. And it is possible that these activities create opportunities otherwise unavailable to the poor. ${ }^{104}$

This, of course, is purely speculation. Perhaps because of the moral opprobrium attached to these activities, there is little careful study of the extent to which the drug or prostitution industry resembles more familiar examples of capitalism. The positive moral foundation of market activity depicts a trade or business in which there are continuous incentives and opportunities for

102. DEP'T OF LABOR, supra note 1 , at 20 .

103. The less voluntary these transactions are, the more readily one can condemn them.

104. See William Finnegan, Out There (pts. 1 \& 2), NEw YORKER, Sept. 10, 1990, at 51-86, Sept. 17 , 1990 , at $60-90$. 
participants to improve their skills and productivity, thus increasing their incomes and job mobility. Such achievements are the byproduct of providing benefits to customers and of increasing societal wealth. It is not evident that the drug trade and prostitution are characterized by these values. Indeed, despite substantial citizen demand and the large monetary stakes involved, it is not apparent that the drug trade increases national wealth in any respect.

Other elements of the illegal economy such as counterfeiting or smuggling possess no positive moral values. These activities appear solely redistributive in character, which is to say that they neither increase societal wealth nor enhance the allocation of resources. There is no current reason to believe that these activities provide systematic opportunities for the disadvantaged. Thus, they are straightforwardly condemned.

\section{B. The Unrecorded and Unreported Economies}

The unrecorded and unreported economies are different from the illegal economy in that they do not constitute a set of activities qualitatively distinct from legal markets; instead, they represent totally lawful economic activities whose participants evade applicable taxes. Tax evasion might seem to be the easiest of rule contraventions to condemn as redistributive, rather than productive, but a more careful analysis is necessary.

Imagine two separate contexts of tax evasion. In the first, a producer evades taxes by misentering sales of $\$ 100,000$ as equal to $\$ 10,000$. In the second, by evading taxes-say, employment taxes-the producer manages to avert insolvency to stay in business or to sell more of the product at a lower price than would be sold otherwise. The first context is an example of a purely redistributive gain; the second, a productive gain. In the first context, the producer becomes richer by exactly the amount of the diminution in tax yield. The net wealth of the society is unchanged. In contrast, in the second context, the tax evasion promotes all of the values previously identified with market activity. The additional sales of the product enhance societal wealth, confer benefits to consumers and provide products for sale at prices lower than otherwise possible, potentially enhancing the position of the least advantaged. In addition, the evasion of the employment tax will increase employment, again potentially aiding either those who are less advantaged to begin with or those who would become less advantaged by losing their employment.

A more precise depiction of the distinction between these contexts can be made. It is well established (and obvious) that the imposition of a tax on a product will increase its price and reduce consumer demand. When price increases, consumers must satisfy their needs by purchasing other, less satisfactory products or, lacking such alternatives, leave those needs unmet. In 
addition, employment in the industry, as well as utilization of other factors of production, will decline. In economics, these effects are described as the deadweight loss of taxation and are represented on a supply and demand graph by a triangle, which incorporates the loss of both consumer and producer surplus.

The distinction between the two contexts of tax evasion above relates to this deadweight loss from taxation. In the second context, the continued production of the good and its sale at a price lower than that charged by producers who pay the tax can be regarded as partially restoring the deadweight loss from the tax. ${ }^{105}$

The evasion of the tax restores the consumer and producer surplus otherwise sacrificed as a casualty of the tax. To the extent of the restoration-and putting aside for now the fiscal effects of evasion-societal welfare is enhanced. More generally, the moral values of the market-wealth creation, superior allocation of resources, distribution of benefits to consumers and of rewards in proportion to these benefits, creation of opportunities for the least advantaged, and the maximization of liberty and respect for personal autonomy-are equally enhanced.

In contrast, in the first context, in which the producer misreported sales of $\$ 100,000$ as equal to $\$ 10,000$, there is no effect on the deadweight loss of taxation. There is only a fiscal effect, presumably negative given the lawful imposition of the tax. There is no restoration of consumer or producer surplus, nor any increase in sales or employment. As a consequence, there is no positive moral basis for the tax evasion.

The deadweight loss analogy can be extended more generally. Those activities of underground economies-whatever the society-that have appeared morally justifiable are similar because they represent efforts to restore deadweight losses created by governmental action. The development of a second agricultural economy in the former Soviet Union represents the effort to reduce the deadweight loss manifested in the chronic shortages created by the Soviet system of state and collective farms. The creation of informal housing settlements in Peru represents the reduction of the deadweight loss created by government land allocation policies and building regulations.

In contrast, elements of underground economies that have no positive effect on the deadweight loss from political policies cannot be morally defended. Counterfeiting, smuggling, and the fraudulent misreporting of sales information have no effect on consumer or producer surplus as defined in economics, because they have no effect on productive output or, at best, a negative effect since real resources are expended to achieve a solely

105. If all producers evaded the tax, the deadweight loss would be completely restored. 
redistributive gain. ${ }^{106}$ The deadweight loss analogy is also helpful in considering the otherwise ambiguous cases of prostitution and the drug trade. The (idealized) defense of prostitution is that it provides through market processes for satisfaction of legitimate human sexual needs without effect, or with positive effect, on the other productive activities of participants. ${ }^{107}$ The debilitating character of addictive drugs is different in this respect. The market for drugs may inflict negative external effects on other productive enterprises, reducing net consumer and producer surplus.

The deadweight loss analogy in itself does not provide a complete answer to the ultimate moral judgment, but it does suggest both positive and normative implications. First, all taxes (and equivalent governmental actions) distort economic activity, but the distortions occur in different ways and the resulting deadweight losses can differ substantially. Speaking strictly of taxes, there will be different levels of deadweight loss according to different products and services taxed and according to how the taxes are imposed. ${ }^{108}$ In the first instance, we might observe that the relative magnitude of underground economies is a measure of the relative degree of deadweight loss from taxation. The evasion of taxes as well as other governmental rules and regulations will be a function, of course, of the penalties for evasion and the likelihood of apprehension. Holding expected penalties constant, however, the productive benefits from evasion are represented by the deadweight loss of taxation. Those activities generating greater levels of productive evasion are likely to be those in which deadweight losses are large. It follows that observations of the underground economy can identify those areas in which the society has most to gain from tax reduction. The larger the extent of productive evasion, the greater the justification for reducing the tax. This, of course, is only a different way of describing the example of the Soviet government ultimately embracing and promoting the second agricultural economy. A more recent example of the same phenomenon is the effort to reduce and simplify the tax reporting requirements for maids and housekeepers in the United States, a reform made compelling by the discovery of widespread employment tax evasion among political leaders and candidates.

The ultimate normative judgment of tax evasion is more complicated. There are no a priori grounds for presuming that all taxes enhance societal welfare. Those who condemn underground economies seem to presuppose that

106. For a similar analysis, see Richard A. Posner, The Social Costs of Monopoly and Regulation, 83 J. POL. ECON. 807 (1975).

107. Again, this is an idealization and ignores the exploitative features of much of the industry.

108. For a discussion of optimal taxation, see ANTHONY B. ATKINSON \& JOSEPH E. STIGLITZ, LECTURES ON PUBLIC ECONOMICS 366-456 (1980). For a more practical approach, see JOSEPH E. STIGLITZ, ECONOMICS OF THE PUBLIC SECTOR 399-411 (1986). 
all government money is spent on true public goods. If this were true, then underground economic activity would diminish social welfare, at least when defined in terms of wealth maximization. That presupposition, however, is highly suspect; no serious student of politics can support it. A moral and economic judgment necessarily requires a comparison of the benefits conferred by the governmental action against the loss from the economic distortion introduced.

\section{The Informal Economy}

In an advanced capitalist country such as the United States, the informal economy largely consists of the evasion of such governmental regulations as immigration restrictions or safety and building codes. Although there are no exhaustive studies of the subject, much of this evasion seems designed to enable the poor to produce goods or provide services at lower cost, or to buy products and services at lower prices than possible otherwise. The Peruvian examples, while more extreme, appear cut from the same cloth.

As with the informal economy of Peru, these examples seem almost entirely market facilitating. Thus, they enhance societal wealth, improve the allocation of societal resources, distribute rewards according to benefits conferred and, most importantly, create new opportunities for the least advantaged. ${ }^{109}$ The moral criticism of these activities must build from a moral defense of some abstractly optimal level of immigration, quality of housing, building, or the like. Much of the political regulation generating these informal activities is defended on the paternalistic grounds that the polity expressing itself through the political process possesses greater information or better judgment than the poor and, therefore that the poor should be prevented from subjecting themselves to the lower standards implied by evasion. It should be remembered, however, that similar expressions of paternalism stood beneath the regulations generating informal economic activities in the former Soviet Union and Peru.

\section{CONCLUSION}

In any society, the constitution of the underground economy reflects the difference between the aggregation of citizen preferences by the political system and the exercise of those preferences in the market. At base, therefore, the moral status of the underground economy stands on the same moral considerations that arise from the differences between the marketplace and

109. This conclusion ignores claims that some amount of undocumented labor or other informal activity suffers exploitation because of its informal character. 
politics as methods of economic organization. The aggregate moral judgment is necessarily ambiguous, though more confident moral conclusions may be reached from the study of individual examples.

No one denies that some public goods exist, which justify some taxation, or that some externalities exist, which justify some level of government regulation. But no one can convincingly argue that all government expenditures create public goods or that all regulations control externalities. Until that is true, the moral values of the marketplace: wealth creation, superior allocation of resources, maximization of individual liberty, the distribution of benefits to consumers and of rewards according to benefits conferred, respect for personal autonomy, and the creation of opportunities for the poor, provide a moral foundation for those underground economic activities that achieve them. 